\title{
Cementless Total Hip Arthroplasty with Subtrochanteric Transverse Shortening Osteotomy in Patients with High Hip Dislocation
}

\author{
Gyo-Wook Kim, MD, Kyung-Jae Lee, MD, Byung-Woo Min, MD, Ki-Cheor Bae, MD, Hyung-Gyu Jang, MD \\ Department of Orthopedic Surgery, Keimyung University School of Medicine, Daegu, Korea
}

Purpose: The purpose of this study was to evaluate the clinical and radiographic results of cementless total hip arthroplasty (THA) with subtrochanteric transverse shortening osteotomy in patients with high hip dislocation. Materials and Methods: Eighteen patients with high hip dislocation who underwent cementless THA combined with a subtrochanteric transverse shortening osteotomy, plate or cable fixation and bone graft on the osteotomy site between 2001 and 2012 were evaluated in this study. The mean duration of follow-up was 5.2 (28.3) years. We evaluated Harris hip score, limping, limb length discrepancy as a clinical parameter and osteolysis, loosening and union of the osteotomy site as a radiographic parameter.

Results: Harris hip scores at the final follow-up showed improvement of limping and limb length discrepancy in all cases. And, with the exception of two cases of infection, there were no loosening and osteolysis. All cases showed union of the osteotomy site. There were two cases of infection and one case of dislocation as a complication. Infection occurred in two patients who underwent reoperation and one patient developed sciatic nerve palsy.

Conclusion: Cementless THA with subtrochanteric transverse shortening osteotomy showed relatively satisfactory clinical and radiologic results. However, the incidence of complications, such as infection, is relatively high, therefore, careful attention is needed.

Key Words: Congenital hip dislocation, Osteotomy, Hip replacement arthroplasty

Submitted: December 31, 2013 1st revision: February 21, 2014 2nd revision: February 26, 2014 Final acceptance: February 27, 2014 Address reprint request to

Gyo-Wook Kim, MD

Department of Orthopedic Surgery, Keimyung University School of Medicine, 56 Dalseong-ro, Jung-gu, Daegu 700-712, Korea

TEL: +82-53-250-8161 FAX: +82-53-250-7205

E-mail: wuk0605Agmail.com

This is an Open Access article distributed under the terms of the Creative Commons Attribution Non-Commercial License (http://creativecommons. org/licenses/by-nc/3.0) which permits unrestricted non-commercial use, distribution, and reproduction in any medium, provided the original work is properly cited.

\section{서 론}

고관절 고위 탈구 환자에서 인공 고관절 전치환술은 변 형된 골구조 및 연부조직 구축 등으로 인해 기술적으로 어 렵고 합병증 역시 많이 발생하는 것으로 알려져 있다 ${ }^{1-8}$. 일 반적으로 정상의 비구 중심보다 약 $4 \mathrm{~cm}$ 이상의 고위 고관 절 중심을 가진 환자에게 인공 고관절 전치환술을 시행할 경우 인공 고관절 기구의 장기 생존을 위해서는, 정확한 해 부학적 고관절 중심부(hip center)를 수복하는 것이 무엇 보다 중요하며 관절의 정복이 적절한 위치에서 이루어져야 한다. 이와 함께 과도한 하지의 연장 및 그로 인한 좌골 신 


\section{Hip \& Pelvis}

Gyo-Wook Kim et al. Cementless Total Hip Arthroplasty in High Hip Dislocation

경손상을 방지하기 위해서 많은 경우에 대퇴골 단축 절골 술이 필요하다 ${ }^{6,9-11)}$. 지금까지 전자간부 ${ }^{12)}$, 근위 골간단부 ${ }^{13)}$, 전자하부 ${ }^{11,14)}$, 원위 대퇴부 ${ }^{14,15)}$ 등과 같이 다양한 부위에서 의 대퇴골 단축 절골술이 개발되어 사용되고 있으며, 이 중 전자하부 단축 절골술은 수술 술기가 쉽고 다양한 교정이 가능하다는 장점으로 최근 많이 시행되고 있으나 회전 불 안정성 및 불유합 가능성으로 인해 수술 시 많은 주의가 필 요하다 ${ }^{6,9,14,16,17)}$. 이에 저자들은 고관절 고위 탈구가 있는 환 자에서 전자하부 횡형 단축 절골술과 함께 무시멘트성 인 공고관절 전치환술을 시행하고 그 임상적 및 방사선학적 결과를 알아보고자 하였다.

\section{대상 및 방법}

2001년 1월부터 2012년 3월까지 발달성 고관절 이형성증 및 감염성 고관절 후유증으로 인해 본원에서 인공 고관절 전치환술을 시행받은 81 명(82예)의 환자 중 Crowe 분류) 제 4형 및 Hartofilakidis 분류 ${ }^{8)}$ C형인 고관절 고위 탈구 환 자로 전자하부 횡형 단축 절골술과 함께 무시멘트 인공 고 관절 전치환술을 시행받고 2 년 이상 추시가 가능하였던 18 명(18예)의 환자를 대상으로 하였다. 수술 전 진단은 발달 성 고관절 이형성증이 13명(13예)이고 감염성 고관절 후유 증이 5명(5예)이었다. 남자가 6명, 여자가 12명이었으며 수술 당시 평균 연령은 43.2세(22-68세), 평균 추시 기간은 5.4년(2-11.5년)이었다.

수술은 모두 단일 술자에 의해 시행되었으며 전 예에서 측와위에서 전외측 도달법으로 시행되었다. 먼저 대퇴 소전 자부 약 $1 \mathrm{~cm}$ 상방에서 대퇴 경부 절골술을 시행하고 가성 및 진성 비구부를 찾아서 확인한 뒤에 대퇴 소전자부로부터 약 $2 \mathrm{~cm}$ 하방에서 횡형으로 단축 절골술을 시행하였다. 이 후 비구부 재건을 먼저 시행하기 위해 진성 비구를 충분히 깊게 확공하여 비구를 최대한 내측화시킨 후 컵을 고정하였 고, 18 예 모두에서 진성 비구에 비구컵을 삽입하였으며 비 구컵의 $30 \%$ 이상이 숙주 비구에 의해 지지되지 못하는 1 예 에서 자가 대퇴 골두를 이용한 골 이식술을 시행하였다.

정복 대퇴 단축을 위한 필요한 절골 길이는 술 전 측정한 골반골 사진을 통해 예상된 절골 길이와 수술 시 삽입물의 시험 정복 결과에 따라 결정되었다. 절골된 대퇴 근위부에 대퇴 시험 삽입물을 삽입하고 정복 후 대퇴 원위부를 부드 럽게 신장시키면서 대퇴 근위부 골절편과 원위부 골절편의 겹침의 정도를 보면서 단계적으로 절골을 시행하였다. 이후 필요한 크기의 대퇴 삽입물을 삽입하고 대퇴부의 전염각을 15-20도로 교정한 뒤에 절골 부위에 회전 안정성을 얻기 위 해서 모든 예에서 추가적으로 금속판 및 케이블을 이용한 고정술을 시행하였다. 그리고, 18 예 모두에서 대퇴 절골부 위에 자가 대퇴 골두를 이용한 골 이식술을 시행하였다.

모든 예에서 무시멘트성 비구컵과 대퇴 삽입물이 사용되
었으며, 비구컵은 8예에서 Triolgy ${ }^{\circledR}$ (Zimmer, Warsaw, IN, USA), 7예에서 Duraloc ${ }^{\mathbb{R}}$ (Depuy, Warsaw, IN, USA), 3예에서 Interop ${ }^{\circledR}$ (Sulzer, Austin, TX, USA)을 사용하였 고, 비구컵의 크기는 평균 $51.1 \mathrm{~mm}(46-58 \mathrm{~mm})$ 였다. 대퇴 삽입물은 술 전 대퇴골의 변형 정도 및 골수강의 넓이에 따 라 다르게 선택하였고, 9예에서 $\mathrm{AML}^{\circledR}$ (Anatomic Medullary Locking; Depuy), 5예에서 Wagner Cone Prosthesis $^{\mathbb{R}}$ (Zimmer), 4예에서 Revitan ${ }^{\mathbb{B}}$ (Zimmer)을 사 용하였다. 인공 관절면은 금속-폴리에틸렌이 11예, 세라믹세라믹이 7예에서 사용되었고, 대퇴 골두는 13예에서 28 $\mathrm{mm}$ 형을, 5 예에서 $36 \mathrm{~mm}$ 형을 사용하였다.

술 후 1 일 후부터 대퇴 사두근 강화 운동을 시작하였고 술 후 약 2 일 후부터는 휠체어 보행을, 술 후 약 2 주 후부터 는 목발이나 보행기를 이용한 부분 체중 부하를 시작하여 술 후 약 8 주까지는 부분 체중 부하를 권장하였다. 이후에 는 방사선 사진의 절골부위 골유합 소견에 따라 전 체중 부 하의 시행 여부를 결정하였다.

예방적 항생제는 수술 절개 1 시간 전과 술 후 6 일까지 투 약하였으며, 모든 환자에게 술 후 1주일 동안 혈전방지 압박 스타킹 및 간혈적 공기 압박 펌프를 사용하였고 술 후 1 주일 째 혈관초음파를 이용하여 심부정맥혈전증을 검사하였다.

환자의 평가는 수술 전, 수술 후 1 개월, 3 개월, 6 개월, 12 개월에 시행하였으며, 이후에는 1년마다 시행하였다. 임상 적 결과는 Harris 고관절 점수, 술 전 및 술 후 하지 부동 및 파행의 정도를 Harris ${ }^{18}$ 의 기준에 따라 걸음걸이에 이상이 없는 경우, 경도, 중등도, 심한 보행 장애로 분류하여 비교 하였다. 방사선학적 결과는 수술 후 촬영한 방사선학적 결 과를 비교 분석하였으며 골용해, 삽입물의 해리 및 절골 부 위의 유합 시기를 조사하였다. 하지 부동은 골반 전후 방사 선 사진에서 좌골 조면 하방을 이은 선과 소전자의 상부와 의 수직 거리로 측정하였으며, 술 후 하지부동은 술 전 하 지부동에서 단축 절골술을 시행한 길이를 반영하여 결정하 였다. 최종 추시상 비구컵 주위의 골 용해를 DeLee와 Charnley ${ }^{19)}$ 의 3 구역으로 나누어 분류하였고 비구컵의 경 사각의 변화, $2 \mathrm{~mm}$ 이상의 수직, 수평 이동 여부를 관찰하 였다 ${ }^{14)}$. 대퇴 삽입물의 고정은 Engh 등 ${ }^{20}$ 의 기준에 따라 골 성안정, 섬유성 안정 및 불안정성으로 구분하였고, 대퇴 삽 입물의 안정성을 판단하는 소견으로는 수직침강을 관찰하 였는데 그 정도는 수술 직후와 최종 추시의 전후면 방사선 사진에서 수직거리가 $5 \mathrm{~mm}$ 이상일 때 의미가 있는 것으로 간주하였다 ${ }^{21}$. 대퇴 전자하 절골술 부위의 골유합 여부는 절골술 부위에 가골이 존재하고 통증이 없으며 전후방 및 측방 방사선 소견에서 피질골의 연속성을 가지며, 정기적 인 방사선 사진상 절골 부위의 간격이 진행되지 않는 경우 골유합이 이루어진 것으로 결정하였다. 합병증 발생 및 재 수술 여부도 조사하였다.

수술 전 후 평가 척도에 대한 통계 분석은 IBM SPSS ver. 


\section{Hip \& Pelvis}

Hip Pelvis 26(1): 22-28, 2014

18.0 (IBM Co., Armonk, NY, USA)를 이용하였다. 수술 전후 임상적 결과의 비교에는 paired t-test를 이용하였으며 비구컵 및 대퇴 삽입물의 종류에 따른 통계적 유의성 확인 에는 Pearson's chi-square test를 이용하였다. 모든 분석의 통계적 유의 수준은 $P$ 값이 0.05 미만인 경우로 하였다.

\section{결 과}

임상적으로 Harris 고관절 점수는 술 전 평균 57.7점(4069점)에서 최종 추시 시 평균 88.3점(65-97점)으로 호전되 었다. 수술 중 절제된 대퇴골은 평균 $3.6 \mathrm{~cm}(1-7 \mathrm{~cm})$ 였으 며 하지 부동은 술 전 평균 $4.7 \mathrm{~cm}(0-8 \mathrm{~cm})$ 에서 최종 추시 시 평균 $0.8 \mathrm{~cm}(0-3 \mathrm{~cm})$ 으로 호전되었다. 양측 고위 탈구 를 가지는 1 예에서 환자 개인 사정으로 좌측 고관절만 수술 을 시행하여 하지 부동이 술 전보다 상대적으로 증가된 경 우가 있었으나, 술 후 추시 상 파행 정도는 호전을 보였다. 이를 제외한 모든 예에서 최종 추시 결과 하지 부동 및 파행 정도 역시 통계적으로 유의한 호전을 보였다(Table 1). 비 구컵에 대한 방사선학적 평가에서는 감염으로 인한 비구컵
이완이 발생하였던 2예를 제외하고는 비구컵의 해리, 골용 해 등을 보인 경우는 없었다. 대퇴 삽입물에 대한 방사선학 적 평가에서는 $5 \mathrm{~mm}$ 미만의 대퇴 삽입물 침강이 1 예에서 관찰되었으나 최종 추시 시까지 침강이 더 진행하지는 않 아 모두 안정된 골성 고정 소견을 보였으며 그 외 대퇴 삽 입물 부위의 골용해나 이완 및 회전정렬의 이상을 보인 예 는 없었다. 평균 16.9주(13-24주)에 절골 부위의 골유합을 얻을 수 있었다(Fig. 1). 합병증은 18 명 중 총 3 명의 환자에 서 4예가 발생하였는데 심부 감염 2예, 좌골 신경 마비 1 예, 탈구가 1 예였다. 심부 감염이 발생한 2 예에서 2 단계 재 치환술을 시행하였으며 그 중 1 예에서 좌골 신경 마비가 발생하였다(Fig. 2). 발생 원인은 정확히 알 수 없었으며, 수술 직후부터 고관절 신전 및 슬관절 굴곡을 시키고 이후 경과 관찰하였으나 1 년 2 개월 최종 추시에서 부분적인 마 비가 남아있어 완전한 회복은 되지 않았다. 탈구가 발생한 1 예는 술 후 11 일째 1 차례의 조기 탈구가 발생하였는데, 주 위 연부 조직 긴장도의 이상소견으로 인한 탈구가 의심되 어 도수 정복 시행 후 환자에 대한 교육 및 물리 치료를 시 행하였으며 이후 추시 과정에서 더 이상의 탈구는 발생하

Table 1. Clinical Results

\begin{tabular}{lccc}
\hline \hline & Preoperative & Postoperative & $P$-value \\
\hline Harris hip score & $57.7(40-69)$ & $88.3(65-97)$ & $<0.05$ \\
Limb-length discrepancy $(\mathrm{cm})$ & $4.7(0-8)$ & $0.8(0-3)$ & $<0.001$ \\
Limping (n) & & & \\
Severe & 15 & 1 & \\
Moderate & 2 & 3 & \\
Mild & 1 & 14 & \\
No & & & \\
\hline
\end{tabular}

Values are presented as data (range) or data only.
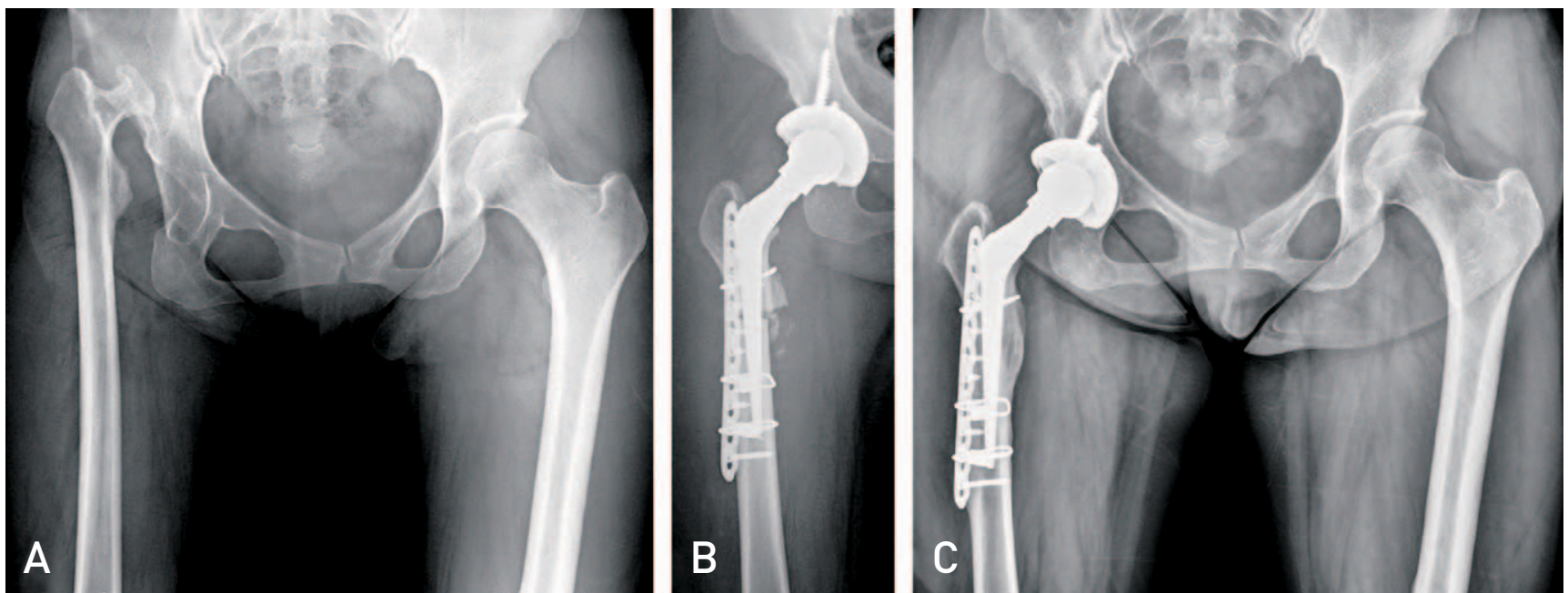

Fig. 1. (A) A preoperative radiograph shows Crowe classification 4 high dislocation of the right hip with about $6 \mathrm{~cm}$ limb-length discrepancy. (B) A postoperative radiograph shows the hip after femoral shortening and total hip replacement on the right side. (C) A postoperative radiograph after 4.5 years shows healing of the osteotomy site and incorporation of the prosthesis. 


\section{Hip \& Pelvis}

Gyo-Wook Kim et al. Cementless Total Hip Arthroplasty in High Hip Dislocation

지 않았다. 술 후 1 주일째 혈관초음파로 시행한 심부정맥 혈전증 검사에서는 모든 환자에서 관찰되지 않았다. 술 전 진단명, 비구컵 종류 및 대퇴 삽입물의 종류에 따른 임상적 및 방사선학적 결과의 통계적으로 유의한 차이는 없었다.

\section{고 찰}

소아에서 발병된 고관절 질환은 고관절 주변의 해부학적 구조물들의 변화를 일으키고 대퇴골의 변형과 고관절 주 변 근육 위축이 동반되어 인공 고관절 치환술 시 많은 어려 움을 준다. 특히 발달성 고관절 이형성증에서는 대퇴 경부 가 짧아짐으로 인한 대전자의 높은 위치, 전경사각의 증가 및 좁은 대퇴 골수강(narrow canal)의 형태 등의 대퇴 부 위 변형이 나타난다 ${ }^{1,2,4)}$. 이러한 형태는 고식적인 대퇴 삽입 물을 사용할 경우 원통형의 골수강에 안착시키기 어려울
뿐 아니라 근위부와 원위부의 안정성을 얻기가 힘들며, 전 경사각의 교정이 불가능하여 수술 시 많은 어려움이 따른 다. 이러한 문제점들로 인해 발달성 고관절 이형성증의 수 술 시 인공 관절 선택에 어려움을 주고 있으며 여러 저자들 의 문헌에서도 인공 고관절 치환술의 시행 후 상대적으로 다른 질환군에 비해서 좋지 않은 결과를 보고하고 있다 ${ }^{1-8)}$.

고관절 이형성증은 Crowe 등ㄱㅇㅔ 의해 아탈구 정도에 따 라 4가지로 분류하였고, Hartofilakidis 등은 대퇴 골두와 비구의 위치에 따라 3가지로 분류하였는데, Crowe 분류 3, 4형 또는 Hartofilakidis 분류 C형인 고위탈구인 경우에는 인공 고관절 치환술 후에 탈구, 신경 손상, 절골술 부위의 불유합 등과 같은 합병증의 발생률이 상대적으로 높다 ${ }^{92,23)}$. 본 연구에서도 총 18 명 중 3명의 환자(4예, 22.2\%)에서 합 병증이 발생하여 높은 합병증 발생률을 보였으며, 특히 감 염 등의 합병증 발생 빈도가 높았다. 따라서 성공적인 수술
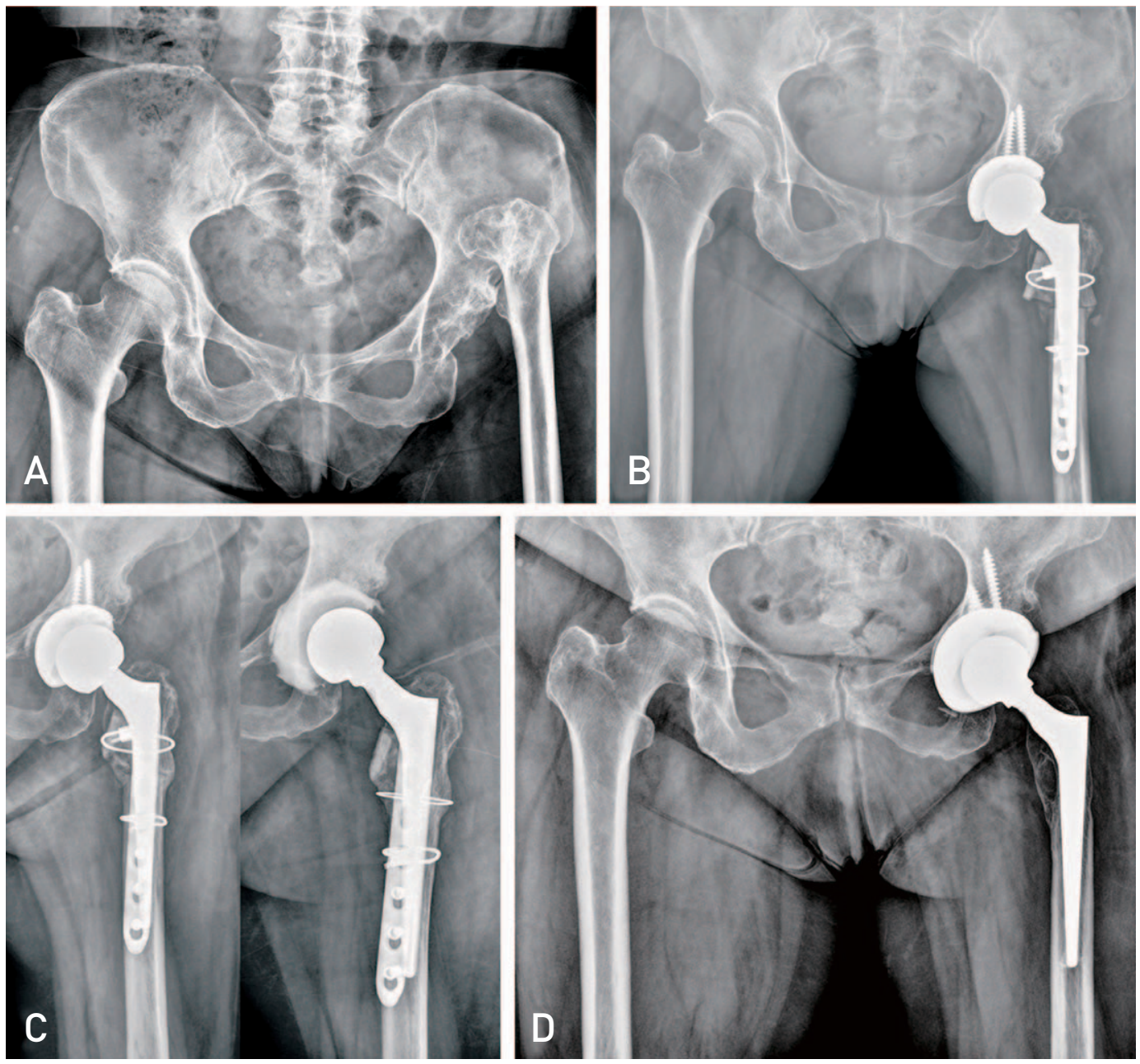

Fig. 2. (A) A preoperative radiograph shows Crowe classification 4 high dislocation of the left hip. (B) A postoperative radiograph shows the hip after femoral shortening and total hip replacement on the left side. (C) A postoperative radiographs show after 6 months acetabular cup loosening caused by infection and after management of infected total hip replacement with PROSTALAC ${ }^{\mathbb{R}}$. But, well-fixed femoral stem was retained. (D) A postoperative radiograph after the second stage revision shows no evidence of periprosthetic osteolysis and implant loosening. 


\section{Hip \& Pelvis}

Hip Pelvis 26(1): 22-28, 2014

을 위해서는 수술 전 철저한 사전 준비와 함께 수술 시행과 정에도 술자의 각별한 주의가 필요하다.

특히 이러한 고관절 이형성증 수술에서 좋은 결과를 얻 기 위해서는 비구컵을 가급적 해부학적 진성 비구의 위치 에 복원하여 삽입하는 것이 매우 중요하며 인공 고관절 전 치환술 시 해부학적 고관절 중심을 얻기 위한 효과적인 방 법으로 대퇴골 단축 절골술이 시행되고 있다. 대퇴골 단축 절골술은 여러 위치에서 시행할 수 있다고 알려져 있으며 여러 저자들에 의해서 전자간부 ${ }^{12)}$, 근위 골간단부 ${ }^{13)}$, 전자하 부 $11,14,17,19)$ 및 원위대퇴부 ${ }^{14,15)}$ 등에서 다양하게 시도되고 있 다. 먼저 전자간부에서의 단축 절골술은 외전 지렛대를 증 가시키고 중둔근의 기능을 향상시켜서 적절한 외전근력을 생성시킬 수 있고, 비구와 대퇴부의 재건 시 효과적이고 안 전한 노출이 가능하며 시술에 10 분 이상 소요되지 않는다 는 장점이 있다 ${ }^{724}$. 하지만 전자간부 절골부위의 불유합이 발생할 가능성이 상대적으로 높아서 최근 10 년간에는 전자 간부 절골술에 비해 전자하부 절골술을 좀 더 선호하고 있 다 ${ }^{22,25)}$. 근위 골간단부에서의 단축 절골술은 하지의 기능적 인 연장이 최대 $3 \mathrm{~cm}$ 정도이고, 어렵고 시간이 많이 들며 근위 절골편의 골절의 위험성이 높은 술식으로 알려져 있 다 ${ }^{15)}$. 대퇴 원위부 단축술은 대전자부 절골단축술을 시행하 지 않으므로 대퇴골 근위부를 보존하여 삽입물의 회전 불 안정성을 줄이고 대퇴 삽입물의 안정된 고정력을 상대적으 로 쉽게 얻을 수 있다는 장점이 있지만, 수술 과정에서 대 퇴골 원위부에 다른 절개선이 필요하고 대퇴 원위부 절골 부위에 추가적인 내고정술이 필요하며 이로 인한 골역학의 변화로 금속판 고정부위에 골다공증이 생길 수 있어 이를 방지하기 위한 금속판 제거술을 다시 시행해야 하는 단점 이 있다 ${ }^{6,11)}$. 전자하부에서의 단축 절골술은 대퇴 근위부의 보존이 가능하며 이는 대퇴 삽입물에 대한 비틀림 안정성 을 증가시켜서 무시멘트성 대퇴 삽입물의 삽입 후 위치 유 지에 도움을 줄 수 있고, 한번의 절골로 대퇴 단축과 회전 이상의 교정을 같이 할 수 있어서 대퇴 근위부의 해부학적 구조의 유지에 도움을 준다. 대퇴의 골절편을 회전함으로 서 대퇴 근위부의 전염각을 교정할 수 있으며 대퇴의 골절 편은 대전자부와 회전근을 해부학적으로 바깥쪽에 위치하 게 하여 회전근 지렛대를 유지할 수 있어 불안정성과 파행 을 최소화할 수 있다. 그와 더불어 전자하 단축 절골술은 대전자의 재부착 및 유합과 관련된 문제점을 피할 수 있는 여러 장점이 있다 ${ }^{6}$. 전자하 단축 절골술의 방법으로는 횡상 (transverse) ${ }^{6}$, 사상 (oblique ${ }^{25)}$, 양측 갈매기형(double chevron) ${ }^{13)}$ 및 계단식(step-shaped ${ }^{26)}$ 절골술 등이 소개되 어 있다. 이 중 횡상 절골술은 대퇴골 단축과 회전 정렬이 용이하며 수술 술기가 비교적 간편하여 가장 흔히 시행되 고 있으나, 대퇴 삽입물의 초기 기계적 고정이 견고하지 못 할 경우 대퇴 삽입물에 의한 스트레스 한계를 악화시키고, 근위부 골 내 성장에 영향을 주어서 회전 불안정성이 증가
되어 상대적으로 불유합의 가능성이 높아질 수 있는 술식 으로 알려져 있다.

여러 논문에서도 이러한 불유합의 문제점에 대해서 언급 하고 있으며 많게는 $14 \%$ 까지 발생될 수 있다고 보고되었다 $11,16,27$. 따라서, 전자하 단축 절골술 후 대퇴 절골 부위에서 회 전 안정성을 유지하고 불유합을 예방하기 위해 여러 저자들 은 다양한 방법을 시도하였다. Kiliçoğlue 등 22$)$ 은 대퇴 절골 부위의 굽힘에 대응하고 회전 안정성을 얻기 위해서 미세 피 복된 원통 모양의 굵은 대퇴 삽입물을 사용함과 동시에 절골 술 시행 부위에는 절제된 대퇴골을 이용하여 외재골 이식 (onlay bone graft)을 시행하고 케이블로 고정하였고, 술 후 $94 \%$ 에서 골유합을 얻었다. Nagoya 등 ${ }^{5}$ 도 좁은 대퇴 골수강 을 가진 환자에서 미세 피복된 원통 모양의 대퇴 삽입물을 사용하여 좋은 결과를 얻었다. Krych 등은 전자하부 횡상 절골술 후에 회전 안정성의 유지가 중요함을 강조하였고 이 를 위해 대퇴 간부 잠금 지주 동종골(autogenous cortical strut grafts)과 케이블을 이용하여 보강할 것을 권유하기도 하였다. 본 연구에서도 수술 시 18예 모두에서 전자하부 단 축 횡상 절골술을 시행하였다. 저자들은 전자하부 절골 부위 에 불유합의 발생을 최소화하기 위해서 절골부위의 회전 안 정성 유지와 원활한 골 내 성장이 반드시 이루어져야 될 것 으로 사료되어, 횡상 절골 부위에 회전 안정성 유지를 위해 18예 모두에서 예방적으로 금속판 및 케이블로 대퇴 절골부 위에 추가 고정을 시행하였고, 골 내 성장에 도움을 주기 위 해서 대퇴 절골부위에 자가 대퇴 골두를 이용한 골 이식술을 모든 예에서 시행하였다. 그 결과 전자하부의 횡상 절골술에 가장 큰 문제점으로 언급되고 있는 절골 부위에서의 불유합 발생 없이 모든 예에서 골유합을 얻을 수 있었다.

본 논문은 연구 대상이 18 예로 비교적 적고, 경과 관찰기 간이 평균 5.4년으로 짭다. 비록 대퇴 삽입물의 종류에 따 른 임상적 및 방사선학적 결과에 통계적인 차이는 없었지 만 수술한 환자들에게 모두 동일한 대퇴 삽입물을 사용하 지 않고 3 가지 다른 종류의 대퇴 삽입물이 사용되었다는 한계점이 있다.

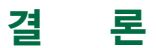

고관절 고위 탈구 환자에서 전자하부 횡형 단축 절골술 을 이용한 무시멘트성 인공 고관절 전치환술은 비교적 만 족할만한 임상적 및 방사선학적 결과를 보였다. 다만 감염 등의 합병증 발생 빈도가 상대적으로 높게 나타나 이에 대 한 각별한 주의가 필요할 것으로 생각된다. 대퇴 전자하부 횡형 단축 절골술 시행 시 금속판 및 케이블 고정과 함께 절골부위의 골이식을 시행하여 모든 예에서 골유합을 얻을 수 있었지만 회전 불안정성에 대한 추가 고정의 필요성 및 방법에 대해서는 좀더 많은 증례를 바탕으로 한 전향적 연 구가 필요할 것으로 생각된다. 


\section{REFERENCES}

1. Charnley J, Feagin JA. Low-friction arthroplasty in congenital subluxation of the hip. Clin Orthop Relat Res. 1973;(91):98-113.

2. Kim YH. Total arthroplasty of the hip after childhood sepsis. J Bone Joint Surg Br. 1991;73:783-6.

3. Sanchez-Sotelo J, Berry DJ, Trousdale RT, Cabanela ME. Surgical treatment of developmental dysplasia of the hip in adults: II. Arthroplasty options. J Am Acad Orthop Surg. 2002; 10:334-44.

4. Pagnano W, Hanssen AD, Lewallen DG, Shaughnessy WJ. The effect of superior placement of the acetabular component on the rate of loosening after total hip arthroplasty. J Bone Joint Surg Am. 1996;78:1004-14.

5. Nagoya S, Kaya M, Sasaki M, Tateda K, Kosukegawa I, Yamashita T. Cementless total hip replacement with subtrochanteric femoral shortening for severe developmental dysplasia of the hip. J Bone Joint Surg Br. 2009;91:1142-7.

6. Krych AJ, Howard JL, Trousdale RT, Cabanela ME, Berry DJ. Total hip arthroplasty with shortening subtrochanteric osteotomy in Crowe type-IV developmental dysplasia. J Bone Joint Surg Am. 2009;91:2213-21.

7. Crowe JF, Mani VJ, Ranawat CS. Total hip replacement in congenital dislocation and dysplasia of the hip. J Bone Joint Surg Am. 1979;61:15-23.

8. Hartofilakidis G, Stamos K, Karachalios T, Ioannidis TT, Zacharakis N. Congenital hip disease in adults. Classification of acetabular deficiencies and operative treatment with acetabuloplasty combined with total hip arthroplasty. J Bone Joint Surg Am. 1996;78:683-92.

9. Lim BH, Moon YW, Lim SJ, Lee HS, Park YS. Modular cementless total hip arthroplasty with subtrochanteric shortening osteotomy in patients with high hip dislocation. J Korean Hip Soc. 2010;22:253-9.

10. Sponseller PD, McBeath AA. Subtrochanteric osteotomy with intramedullary fixation for arthroplasty of the dysplastic hip. A case report. J Arthroplasty. 1988;3:351-4.

11. Cho CH, Yoo MC, Cho YJ, Lee YW, Kwon HG. Total hip replacement in unreduced hip dislocation. J Korean Orthop Assoc. 1999;34:17-22.

12. Malchau H, Kärrholm J, Wang YX, Herberts P. Accuracy of migration analysis in hip arthroplasty. Digitized and conventional radiography, compared to radiostereometry in 51 patients. Acta Orthop Scand. 1995;66:418-24.

13. Hartofilakidis G, Karachalios T. Total hip arthroplasty for congenital hip disease. J Bone Joint Surg Am. 2004;86-A: 242-50.

14. Eskelinen A, Helenius I, Remes V, Ylinen P, Tallroth K, Paavilainen T. Cementless total hip arthroplasty in patients with high congenital hip dislocation. J Bone Joint Surg Am. 2006;88:80-91.

15. Koulouvaris P, Stafylas K, Sculco T, Xenakis T. Distal femoral shortening in total hip arthroplasty for complex primary hip reconstruction. A new surgical technique. J Arthroplasty. 2008;23:992-8.

16. Reikerås O, Haaland JE, Lereim P. Femoral shortening in total hip arthroplasty for high developmental dysplasia of the hip. Clin Orthop Relat Res. 2010;468:1949-55.

17. Takao M, Ohzono K, Nishii T, Miki H, Nakamura N, Sugano N. Cementless modular total hip arthroplasty with subtrochanteric shortening osteotomy for hips with developmental dysplasia. J Bone Joint Surg Am. 2011;93: 548-55.

18. Harris WH. Traumatic arthritis of the hip after dislocation and acetabular fractures: treatment by mold arthroplasty. An end-result study using a new method of result evaluation. J Bone Joint Surg Am. 1969;51:737-55.

19. DeLee JG, Charnley J. Radiological demarcation of cemented sockets in total hip replacement. Clin Orthop Relat Res. 1976;(121):20-32.

20. Engh CA, Massin P, Suthers KE. Roentgenographic assessment of the biologic fixation of porous-surfaced femoral components. Clin Orthop Relat Res. 1990;(257): 107-28.

21. Becker DA, Gustilo RB. Double-chevron subtrochanteric shortening derotational femoral osteotomy combined with total hip arthroplasty for the treatment of complete congenital dislocation of the hip in the adult. Preliminary report and description of a new surgical technique. J Arthroplasty. 1995;10:313-8.

22. Kiliçoğlu Oí, Türker M, Akgül T, Yazicioğlu O. Cementless total hip arthroplasty with modified oblique femoral shortening osteotomy in Crowe type IV congenital hip dislocation. J Arthroplasty. 2013;28:117-25.

23. Lee SH, Kim BK, Ahn JY, Hwang JH, Lee DH. Short term results of cementless total hip arthroplasty with subtrochanteric shortening osteotomy in severe dysplasia of hip. J Korean Hip Soc. 2007;19:136-43.

24. Bruce WJ, Rizkallah SM, Kwon YM, Goldberg JA, Walsh WR. A new technique of subtrochanteric shortening in total hip arthroplasty: surgical technique and results of 9 cases. J Arthroplasty. 2000;15:617-26.

25. Sener N, Tözün IR, Aşik M. Femoral shortening and cementless arthroplasty in high congenital dislocation of the hip. J Arthroplasty. 2002;17:41-8.

26. Fujishiro T, Nishiyama T, Hayashi S, Kurosaka M, Kanno $\mathrm{T}$, Masuda T. Leg length change in total hip arthroplasty with subtrochanteric femoral shortening osteotomy for Crowe type IV developmental hip dysplasia. J Arthroplasty. 2012;27:1019-22.

27. Huo MH, Zatorski LE, Keggi KJ. Oblique femoral osteotomy in cementless total hip arthroplasty. Prospective consecutive series with a 3-year minimum follow-up period. J Arthroplasty. 1995;10:319-27. 


\section{국문초록}

\section{고관절 고위 탈구 환자에서 전자하 횡형 단축 절골술을 이용한 무시멘트성 인공 고관절 전치환술 \\ 김교욱 · 이경재 · 민병우 · 배기철 - 장형규 \\ 계명대학교 의과대학 정형외과학교실}

목적: 고관절 고위 탈구 환자에서 전자하 횡형 단축 절골술을 이용하여 무시멘트성 인공 고관절 전치 환술을 시행하고 그 임상적 및 방사선학적 결과를 알아보고자 하였다.

대상 및 방법: 2001년부터 2012년까지 고관절 고위 탈구로 대퇴 전자하부 횡형 단축 절골술과 함께 금속판 또는 케이블 고정 및 절골부위의 골이식을 시행하여 무시멘트성 인공 고관절 전치환술을 시행 하였던 환자 18 명(18예)을 대상으로 하였다. 평균 추시 기간은 5.2 년(2-8.3년)이었다. 임상적으로 Harris 고관절 점수, 파행, 하지 부동의 변화를 측정하였고, 방사선학적으로 골용해, 삽입물의 해리 및 절골 부위의 유합 유무를 평가하였다.

결과: 최종 추시 시 전 예에서 Harris 고관절 점수, 파행 및 하지 부동의 호전이 관찰되었다. 방사선 학적으로 감염이 발생했던 2예를 제외한 전 예에서 삽입물의 해리, 골용해 등을 보인 경우는 없었으 며, 전 예에서 절골부의 유합 소견을 보였다. 합병증으로 감염 2예, 탈구 1 예가 있었으며 감염으로 재 수술을 시행한 2 예 중 1 예에서 좌골 신경 마비가 발생하였다.

결론: 고관절 고위 탈구 환자에서 전자하부 횡형 단축 절골술을 이용한 무시멘트성 인공 고관절 전치 환술은 비교적 만족할 만한 결과를 보였다. 그러나 감염 등의 합병증 발생이 상대적으로 높게 나타나 이에 대한 각별한 주의가 필요할 것으로 생각된다.

색인단어: 선천성 고관절 탈구, 절골술, 인공 고관절 전치환술 